Historic, Archive Document

Do not assume content reflects current scientific knowledge, policies, or practices. 



\section{ANNUAL WHOLESALE PRICE LIST FALL 1926 - SPRING 1927}

\section{F R A S E R

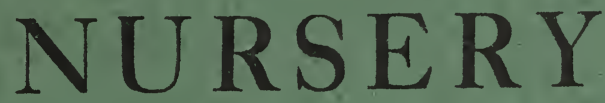 \\ COMPANY}

(INCORPORATED)

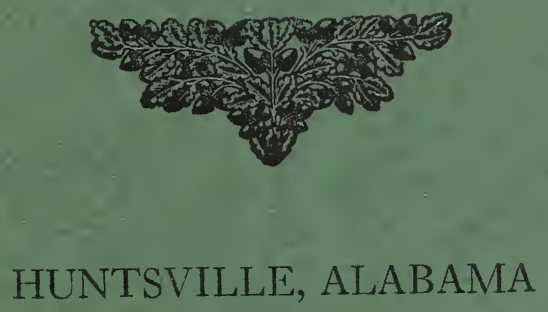

IT PAYS PIC TO PLANT

FOR NURSERYMEN, FLORISTS, SEEDSMEN AND DEALERS ONLY 



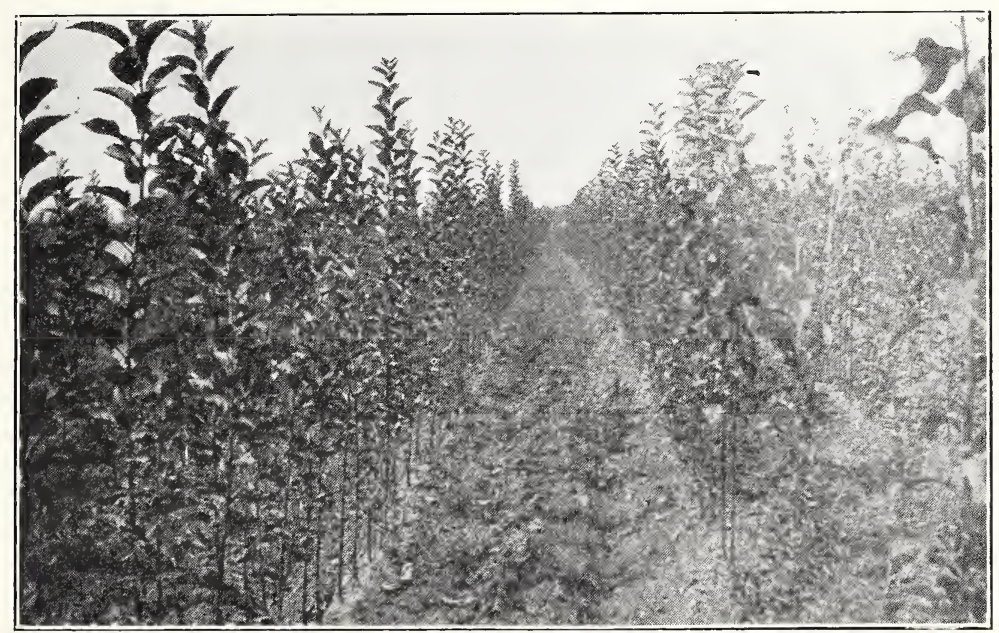

One-Year Budded Apple

\section{FRUIT TREES}

\section{APPLE-Budded}

2 years, 5 to 7 feet, 11/16 and up, well branched

2 years, 4 to 5 feet, $9 / 16$ to $11 / 16$, well branched

2 years, 3 to 4 feet, $7 / 16$ to $9 / 16$, well branched

1 year, 6 to 7 feet, whips and branched

1 year, 5 to 6 feet, whips and branched

Gallop

1 year, 4 to 5 feet, whips and branched

Garage

\section{Delicious}

\section{Early Harvest}

Kinnaird (2 year only)

Livland (Livland Raspberry)

Red June (2 year only)

Staymen Winesap (2 year only)

Winesap (2 year only)
Yates (2 year only)

Yellow Horse

Yellow Transparent

Crabs

Hyslop (2 year only)

Transcendent (2 year only)
Per 100

$\$ 35.00$

25.00

15.00

30.00

25.00

20.00

15.00

Georgia, February 2, 1920 .-We have received our first shipment of rhubarb roots, and they opened up very nicely.

Tennessee, March 29, 1926.-My previous orders arrived in very good shape. Kindly send me the following at once:

Tennessee, April 3, 1926-I am to-day sending check closing account. Thanking you for the nice plants and prompt service rendered, I am . . .

North Carolina, March 15, 1926.-The order of one hundred Irish Junipers was received in splendid condition. We are sure that none will be lost, owing to your prompt shipment and firm packing. 


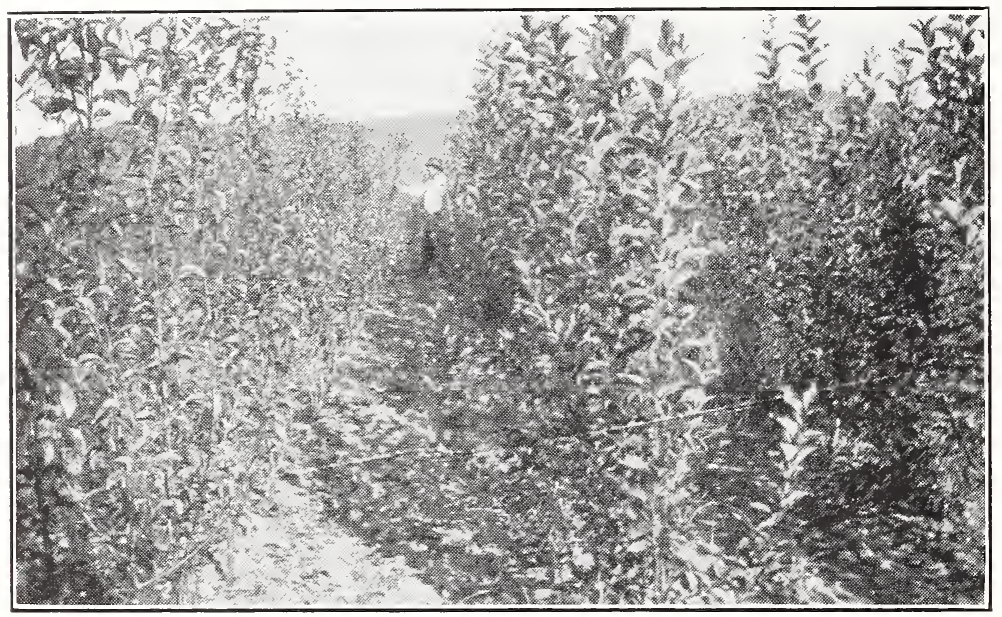

Our One-Year Budded Pears Are the Finest We Ever Saw

\section{STANDARD PEAR - Budded on Japan}

\begin{tabular}{|c|c|c|}
\hline & Cipher & Per 100 \\
\hline 2 years, 6 to 8 feet, 1 inch and up, well branched & Hack & $\$ 60.00$ \\
\hline 2 years, 5 to 7 feet, $11 / 16$ to 1 inch, well branched & Hackle & 45.00 \\
\hline 2 years, 4 to 5 feet, $9 / 16$ to $11 / 16$, well branched & Haddock & 30.00 \\
\hline 2 years, 3 to 4 feet, $7 / 16$ to $9 / 16$, branched & Halt & 20.00 \\
\hline 1 year, 6 to 7 feet, whips and branched & Ham & 45.00 \\
\hline 1 year, 5 to 6 feet, whips and branched & Hame & 35.00 \\
\hline year, 4 to 5 feet, whips and branched & Hand & 30.00 \\
\hline vear, 3 to 4 feet, whips and branched & Happy & 20.00 \\
\hline year, 2 to 3 feet, whips & Harbor & 12.50 \\
\hline Bartlett & & \\
\hline
\end{tabular}

\section{SWEET CHERRY - On Mahaleb}

2 years, 5 to 7 feet, 1 inch and up, well branched _. Ice

2 years, 5 to 6 feet, $11 / 16$ to 1 inch, well branched . Ideal

2 years, 4 to 5 feet, $9 / 16$ to $11 / 16$, well branched ..... Idolize

2 years, 3 to 4 feet, $7 / 16$ to $9 / 16$, branched _._. Identify

1 year, 6 to 7 feet, whips and branched _........ Ides

1 year, 5 to 6 feet, whips and branched .............. Idler

1 year, 4 to 5 feet, whips and branched

1 year, 3 to 4 feet, whips and branched _....... Ignoble

60.00

50.00

40.00

25.00

50.00

45.00

35.00

Black Tartarian

\section{Gov. Wood}

25.00

\section{SOUR CHERRY - On Mahaleb}

2 years, 5 to 7 feet, 1 inch and up, we 11 branched Ignore

2 years, 5 to 6 feet, $11 / 16$ to 1 inch, we 11 branched

40.00

2 years, 4 to 5 feet, $9 / 16$ to $11 / 16$, well branched

2 years, 3 to 4 feet, $7 / 16$ to $9 / 16$, branched

Illicit

27.50

1 year, $3 \frac{1}{2}$ to $4 \frac{1}{2}$ feet, $11 / 16$ and up, well branched

Illness

20.00

1 year, 3 to $4 \frac{1}{2}$ feet, $9 / 16$ to $11 / 16$, well branched

Illude

40.00

1 year, $2 \frac{1}{2}$ to $3 \frac{1}{2}$ feet, $7 / 16$ to $9 / 16$, well branched

Image

27.50

Large Montmorency

Richmond (Early Richmond) 


\section{PEACH}

$\begin{array}{ll}1 \text { year, } 5 \text { to } 7 \text { feet, } 11 / 16 \text { and } \text { up, well branched } \\ 1 \text { year, } 4 \text { to } 5 \text { feet, } 9 / 16 \text { to } 11 / 16 \text {, well branched } \\ 1 \text { year, } 3 \text { to } 4 \text { feet, } 7 / 16 \text { to } 9 / 16 \text {, branched } \\ 1 \text { year, } 2 \text { to } 3 \text { feet, } 5 / 16 \text { to } 7 / 16 \text {, partly branched } \\ \text { Alexander } & \text { Greensboro } \\ \text { Arp Beauty } & \text { Heath Cling } \\ \text { Belle of Georgia } & \text { Hiley } \\ \text { Carman } & \text { J. H. Hale } \\ \text { Champion } & \text { Krummel } \\ \text { Chinese Cling } & \text { Mayflower } \\ \text { Crawford's Early } & \text { Rochester } \\ \text { Crawford's Late } & \text { Salway } \\ \text { Elberta } & \text { Wonderful }\end{array}$

Cipher Jaguar Jersey Jobber Join
Per 1,000

$\$ 250.00$

220.00

150.00

100.00

Fitzgerald

\section{QUINCE}

2 years, $5 / 8$ and up, well branched

Quake

2 years, $1 / 2$ to $5 / 8$, well branched Quarter

\section{Champion}

\section{Orange}

\section{PLUM-One Year, on Plum}

5 to 7 feet, 1 inch and up, well branched

Kago

5 to 6 feet, $11 / 16$ to 1 inch, well branched

4 to 5 feet, $9 / 16$ to $11 / 16$, well branched Kendal

3 to 4 feet, $7 / 16$ to $9 / 16$, branched

Kennel

\section{Abundance}

Burbank

Red June
Wickson

Shropshire Damson

\section{FIGS}

1 year, 3 to 4 feet, whips and branched Family

1 year, 2 to 3 feet, whips and branched Fan

1 year, 18 to 24 inches, whips Brown Turkey Fancy

\section{JAPANESE PERSIMMON-Grafted}

1 year, 3 to 4 feet, whips

Myriad

1 year, 2 to 3 feet, whips

Hacheya

Hyakume

Okame

Tane Nashi
Triumph

Yemon

Zengi
45.00

35.00

25.00

18.00

\section{Celestial}

Mystery

\section{NUT TREES}

PECANS, Standard Varieties

4 to 5 feet

2 to 3 feet

Pend 
NUT TREES-(Continued)

BLACK WALNUT

4 to 5 feet

Cipher

Wall

3 to 4 feet

War

2 to 3 feet

Wax

18 to 24 inches

Well

\section{ENGLISH WALNUT}

$\begin{array}{lr}3 \text { to } 4 \text { feet } & \mathbf{6 0 . 0 0} \\ 2 \text { to } 3 \text { feet } & \mathbf{5 0} .00 \\ 18 \text { to } 24 \text { inches } & \mathbf{3 5 . 0 0}\end{array}$

\section{SMALL FRUITS}

BLACKBERRY - Transplants

Blowers

Early Harvest

Eldorado

DEWBERRY - Transplants

One Year, Tips.

Austin

\section{Mersereau}

Snyder

\section{RASPBERRY}

Cumberland (Black) Transplants

Cumberland (Black) One Year No. I

Cuthbert (Red) Transplants

Cuthbert (Red) One Year, No. 1

St. Regis (Everbearing) Transplants

35.00

St. Regis (Everbearing) One Year, No. 1

\section{GARDEN ROOTS}

ASPARAGUS-Two Year crowns, all standard varieties

\section{GRAPES}

\section{Two Years, No. 1.}

Campbell's Early

Per 100

Concord

Diamond (Moore's Diamond) 


\section{VINES}

AMPELOPSIS tricuspidata veitchi (Boston Ivy) Cipher Per 100

2 years, No. 1 . Vicar

CLEMATIS henryi, white, 2 years, No. 1

Vicious

jackmanii, purple, 2 years, No. 1 Victim

40.00

40.00

paniculata, 2 years No. 1

View

40.00

18.00

HEDERA helix (English Ivy)

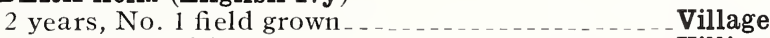

1 year, from $2 \frac{1}{2}$ inch pots

Villian

30.00

20.00

PUERARIA thunbergiana (Kudzu Vine)

2 years, No. 1_. Violin

12.00

\section{PRIVET}

LIGUSTRUM AMURENSE (Amour River Hardy) Cipher

3 to 4 feet, 4 branches and up

Power

3 to 4 feet, 2 and 3 branches.

Practice

2 to 3 feet, 4 branches and up

Prairie

2 to 3 feet, 2 and 3 branches

Prance

18 to 24 inches, 3 branches and up

Prank

18 to 24 inches, 2 branches

Prate

12 to 18 inches, 3 branches and up

Prattle

12 to 18 inches, 2 branches

Prayer

6 to 12 inches, 3 branches and up

Preach

Per 1,000

$\$ 85.00$

75.00

75.00

65.00

60.00

50.00

50.00

35.00

25.00

\section{IBOTA}

2 to 3 feet, well branched

Prejudice

18 to 24 inches, branched Prebend

120.00

80.00

12 to 18 inches, branched

Precede

50.00

JAPONICUM (Japanese Privet) (See Broad Leaved Evergreens)

OVALIFOLIUM (California Privet)

2 to 3 feet, 4 branches and up....... Precept

2 to 3 feet, 2 and 3 branches _... Precious

18 to 24 inches, 3 branches and up _._. . Precise

18 to 24 inches, 2 branches $\ldots$

12 to 18 inches, 3 branches and up .

12 to 18 inches, 2 branches....... Predict

6 to 12 inches, 3 branches and up _._. Preface

Transplanting grade, suitable alse for grafting _._. Prefer

REGELIANUM (Regels or Prostrate Privet)

24 to 30 inches, well branched

Prefix

18 to 24 inches, well branched

Preamble

150.00

12 to 18 inches, well branched

Prelate

120.00

80.00

\section{SINENSE (Amour River-Southern Type)}

2 to 3 feet, well branched 


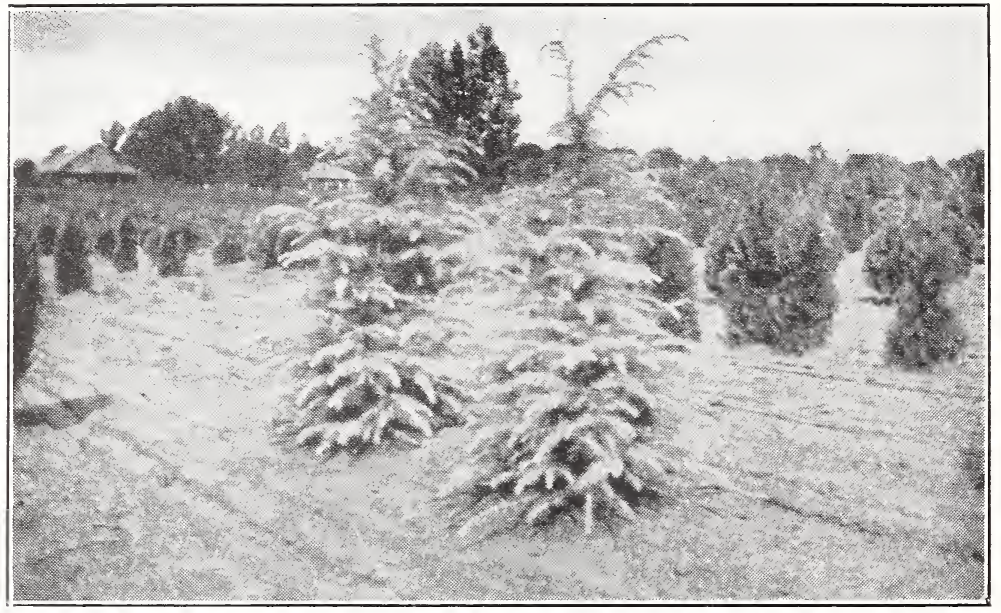

Cedrus Deodara, Showing Sheared Specimens

\section{CONIFEROUS EVERGREENS}

Prices include balling and burlapping where necessary.

\section{CEDRUS deodara}

5 to 6 feet, sheared

4 to 5 feet, sheared

3 to 4 feet, sheared

30 to 36 inches, shéared

24 to 30 inches, sheared

18 to 24 inches
Cipher

Eager

Ear

Earl

Ease

Eat

Eaves

\section{CHAMAECYPARIS (Retinospora) Japan Cypress} Lawsoniana (Lawson Cypress)

24 to 30 inches

18 to 24 inches

15 to 18 inches

obtusa

4 to 5 feet

3 to 4 feet

30 to 36 inches

\section{pisifera}

30 to 36 inches, sheared _............. Eddy

24 to 30 inches, sheared

18 to 24 inches, sheared

Edge

Edict
Per 10

$\$ 60.00$

50.00

40.00

35.00

30.00

20.00
Per 100

$\$ 225.00$

150.00

100.00

40.00

30.00

25.00

\section{pisifera aurea}

3 to 4 feet, sheared _............... Educate

30 to 36 inches, sheared _..._._._._. Effect

24 to 30 inches, sheared ................. Effigy

18 to 24 inches, sheared . . . . Effort 


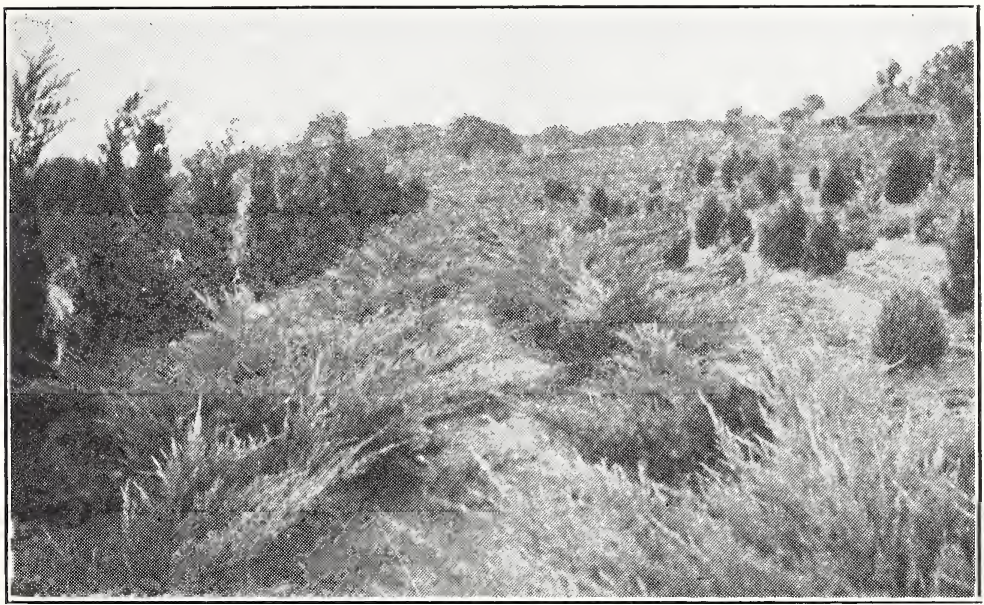

Some of the Juniperus Pfitzeriana We Are Offering This Year

CONIFEROUS EVERGREENS-(Continued).

CHAMAECYPARIS pisifera plumosa(Green) Cipher

3 to 4 feet, sheared.

30 to 36 inches, sheared

24 to 30 inches, sheared

18 to 24 inches, sheared

isifera squarrosa veitchii

(Veitch's Silver Cypress)

4 to 5 feet

3 to 4 feet

30 to 36 inches

24 to 30 inches

18 to 24 inches

CUPRESSUS arizonica (Arizona Cypress)

24 to 30 inches

18 to 24 inches

Elate
Elbow

Elegit

Elegy

Element

Elemental

24 to 30 inches

18 to 24 inches

$$
\text { Figg }
$$

Egress

Eject

Elapse

JUNIPERUS chinensis pfitzeriana

(Pfitzer's Chinese Juniper)

30 to 36 inches, spread

Elephant

24 to 30 inches, spread

Elevate

18 to 24 inches, spread

Elf

15 to 18 in hes, spread

Elide

Per $10 \quad$ Per 100
$\$ 300.00$
250.00
200.00
150.00

$\$ 45.00$

35.00

25.00

200.00

150.00

200.00

150.00

communis (Common Juniper)
4 to 5 feet, sheared
Eligible
3 to 4 feet, sheared
Elocution
30 to 36 inches, sheared
Elope
24 to 30 inches, sheared
Elusive

30.00

250.00

200.00

150.00 


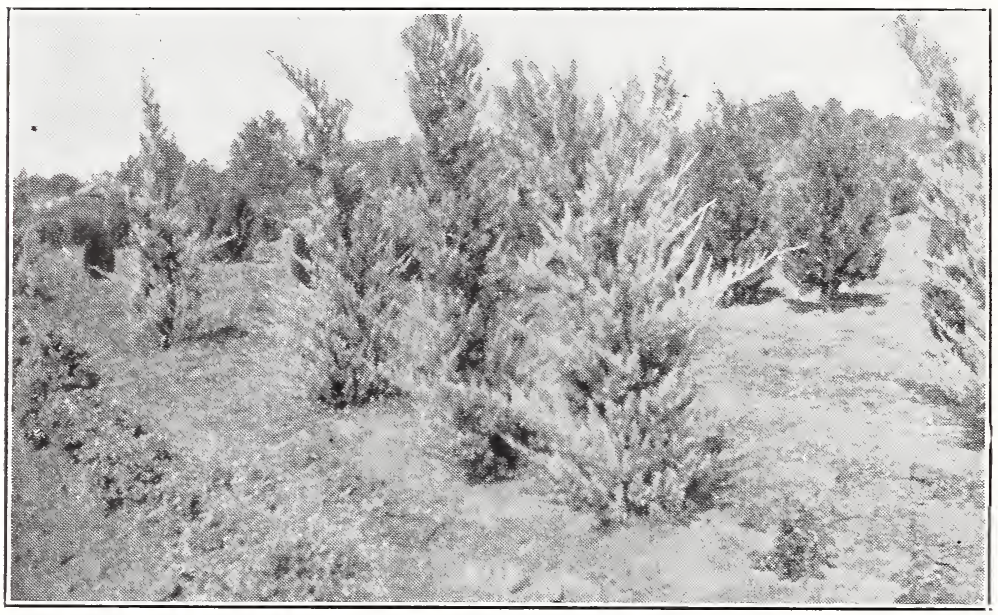

Juniperus Virginiana Glauca Are Sheared and Fine

CONIFEROUS EVERGREENS-(Continued).

Cipher

JUNIPERUS communis hibernica (Irish Juniper)

30 to 36 inches, well filled

24 to 30 inches, well filled

18 to 24 inches, well filled

excelsa stricta (Greek Juniper)

24 to 30 inches, well formed

18 to 24 inches, well formed

15 to 18 inches, well formed
Embank

Embassy

Emblem

Embrace

Emend

Emery

Per 10 Per 100

virginiana (Red Cedar)

6 to 7 feet, sheared specimens

Emmet

5 to 6 feet, sheared specimens

Emotion

4 to 5 feet, sheared specimens

Empire

3 to 4 feet, sheared

Employ

30 to 36 inches, sheared

Empress

24 to 30 inches, sheared

Eminent

18 to 24 inches, sheared

Emissary

$\$ 150.00$

100.00

75.00

200.00

150.00

125.00

virginiana cannarti

5 to 6 feet, sheared ___Emit $\quad 75.00$

4 to 5 feet, sheared . Emulate

3 to 4 peet, sheared . . Enact

30 to 36 inches, sheared Enamel

$\$ 65.00$

55.00

40.00

30.00

200.00

150.00

100.00

virginiana glauca (Virginia Blue Cedar)

5 to 6 feet, sheared _._. Encamp

60.00

50.00

40.00

4 to 5 feet, sheared . . . . . . Enchant

75.00

60.00

3 to 4 feet, sheared

Enclose

30 to 36 inches, sheared _. _... Encore

45.00

35.00

24 to 30 inches, sheared

Encroach

27.50 
CONIFEROUS EVERGREENS-(Continued).

\begin{tabular}{|c|c|c|}
\hline $\begin{array}{l}\text { LIBOCEDR US decurrens (Incense Cedar) } \\
30 \text { to } 36 \text { inches } \\
24 \text { to } 30 \text { inches } \\
18 \text { to } 24 \text { inches }\end{array}$ & $\begin{array}{l}\text { Cipher } \\
\text { Endanger } \\
\text { Endeavor } \\
\text { Endless }\end{array}$ & $\begin{array}{l}\text { Per } 10 \text { Per } 100 \\
\$ 35.00 \\
30.00 \\
20.00\end{array}$ \\
\hline
\end{tabular}

THUYA occidentalis (American Arborvitae)

30 to 36 inches 30 inches
18 to 24 inches 18 inches
15 to 18 Endomy

occidentalis Tom Thumb

30 to 36 inches, spread

Enforce

250.00

24 to 30 inches, spread

Engage

18 to 24 inches, spread

Engine

200.00

150.00

occidentalis globosa (Globe Arborvitae)

18 to 24 inches

Engross

15 to 18 inches

Engulf

12 to 15 inches

Enhance

150.00

125.00

100.00

occidentalis hoveyi (Hovey's Golden Arborvitae)

30 to 36 inches.

24 to 30 inches. Enlist

250.00

200.00

18 to 24 inches

Ensemble

150.00

occidentalis George Peabody

30 to 36 inches, well filled

24 to 30 inches, well filled

Ensnare

30.00

25.00

18 to 24 inches, well filled.

Entail

Entire

20.00

occidentalis pyramidalis (Pyramidal Arborvitae)

30 to 36 inches, well filled

Envelope

225.00

175.00

24 to 30 inches, well filled

Enviable

18 to 24 inches, well filled

Envoy

135.00

THUYA orientalis (Biota) (Chinese Arborvitae)

4 to 5 feet, selected, well formed _._._Epic

3 to 4 feet, selected, well formed . . Epicure

30 to 36 inches, well formed _. _ _ _ _ _ Epigram

24 to 30 inches, well formed

18 to 24 inches ...................... Epoch

250.00

150.00

100.00

75.00

50.00

orientalis aurea nana (Berckmans' Golden Arborvitae)

30 to 36 inches, shapely plants . . . . . Equable

24 to 30 inches, shapely plants _. _ _. Equator

18 to 24 inches, shapely plants _..._. _ _ Equip

15 to 18 inches, shapely plants

Era

35.00

25.00

200.00

150.00

TSUGA canadensis (Hemlock Spruce)

30 to 36 inches, well filled.

Eradicate

Erase

30.00

24 to 30 inches, well filled

Erect

22.50

18 to 24 inches

17.50

Arkansas, February 4, 1926.-Inclosed herewith find my check for $\$ 35.50$ for bill of trees shipped January 15. They were a lot of nice stcok all the way through. Will send more orders soon. 


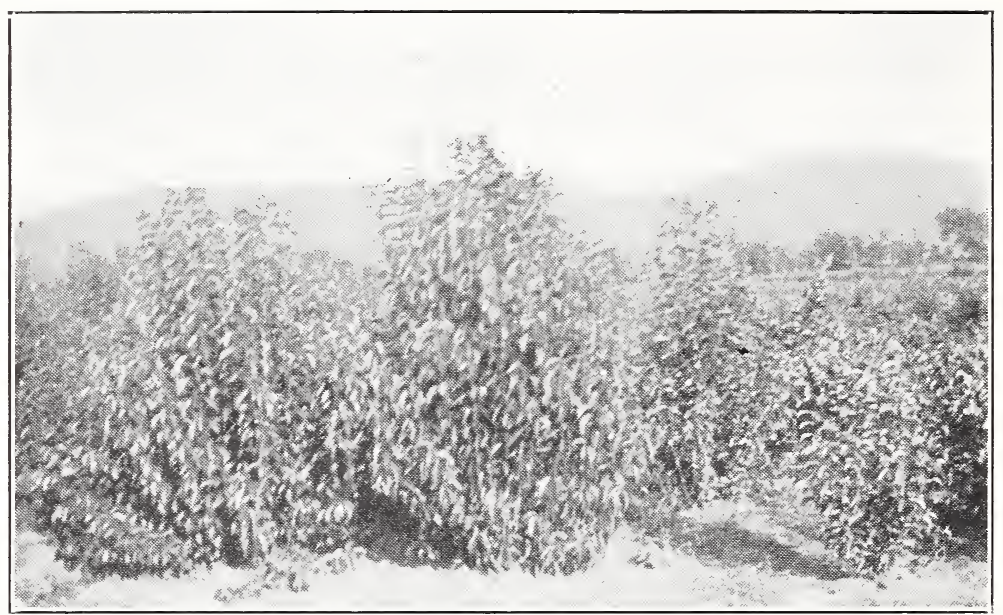

Ligustrum Japonicum-the Large-Leaf Type

\section{BROAD LEAVED EVERGREENS}

Prices include balling and burlapping where necessary.

ABELIA grandiflora (Rupestris)

2 to 3 feet, well branched.

18 to 24 inches, well branche d

12 to 18 inches, well branched
Cipher

Ergo

Ermine

Erode
Per 10 Per 100

$\$ 35.00$

25.00

20.00

30.00

25.00

15.00

Errand

Escape

Escort

6 to 10 inches

Eskimo

Essay

Essence

100.00

75.00

50.00

75.00

60.00

45.00

35.00

25.00

65.00

50.00

35.00

LAUROCERASUS caroliniana (Carolina Cherry)

3 to 4 feet, well branched _. Ether

30 to 36 inches, well branched . . . . . Ethical

24 to 30 inches, well branched _... . _. Elogy

18 to 24 inches, well branched

Evade 
BROAD LEAVED EVERGREENS-(Continued).

\section{LAURUSTINUS (Viburnum tinus)}

24 to 30 inches, well branched

18 to 24 inches, well branched

15 to 18 inches, well branched
Cipher

Evaporate

Evasion

Even

LIGUSTRUM japonicum (Japanese Privet)

5 to 6 feet, well branched

4 to 5 feet, well branched

3 to 4 feet, well branched

2 to 3 feet, well branched
Eventful

Evert

Evict

Evidence
Per 10 Per 100
$\$ 15.00$
12.50
10.00

$\$ 150.00$

100.00

85.00

60.00

20.00

15.00

10.00

250.00

200.00

150.00

125.00

200.00

150.00

125.00

100.00

75.00

\section{MAGNOLIA grandiflora}

2 to 3 feet, well branched

Example

30 to 36 inches, well branched

Exasperate

Excavate

18 to 24 inches, well branched

Exceed

Excel

18 to 24 inches, well branched

Excellent

Except

MAHONIA acquifolia (Oregon Grape)

24 to 30 inches

Excess

15.00

18 to 24 inches

Excise

12.50

15 to 18 inches

Exclaim

10.00

12 to 15 inches

Exclude

8.50

japonica (Holly Leaf Mahonia)

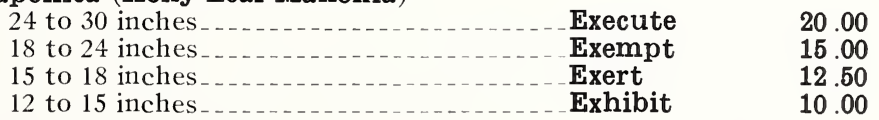

NANDINA domestica

15 to 18 inches

Exile

12.50

12 to 15 inches

Expel

10.00

PACHYSANDRA terminalis (Japanese Spurge) (See Hardy Perennials) PHOTINIA serrulata
4 to 5 feet, well branched
Expire
3 to 4 feet, well branched
Explain
30 to 36 inches, well branched
Explicit
24 to 30 inches, well branched
Export
18 to 24 inches, branched
Extant

25.00

\section{PYRACANTHA lalandii}

2 to 3 feet, well branched

Extol 


\section{ORNAMENTAL TREES}

CERCIS canadensis (Red Bud)

6 to 8 feet
5 to 6 feet
4 to 5 feet
3 to 4 feet

MALUS ioensis bechteli (Bechtel's Double Flowering Crab)

2 to 3 feet, branched

18 to 24 inches, branched

Oblate

Oblige

MELIA azedarach umbracuififcrmis (Texas Umbrella)
8 to 10 feet, well branched
6 to 8 feet, well branched
5 to 6 feet, well branched
4 to 5 feet, well branched
Oblong
Obscure
Observe
Obsess
4 to 5 feet, whips
Obsolete
3 to 4 feet, whips

Per 10 Per 100
$\$ 10.00$
7.50
6.00
5.00

5.00

3.50

12.50

7.50

6.00

5.00

$\$ 40.00$

30.00

75.00

60.00

50.00

40.00

30.00

40.00

30.00

25.00

\section{DECIDUOUS SHRUBS}

\section{ALTHEA-Bush For m, Two Years}

3 to 4 feet, well branched

2 to 3 feet, well branched

18 to 24 inches, well branched
Cipher

Saber

Sac

Sacred
Per 100

$\$ 25.00$

17.50

12.50

Ardens-double violet

Anemoneoflora-large double red

Boule de Feu-very double, bright red

Compte de Hainaut-double, pinkish white

Duc de Brabant-very double, dark red

Jeanne d'Arc-double, pure white

Lady Stanley-semi-double, rosy white

Lavender-double lavender

Poenoeflora-very double, rosy pink

Princess Louise-double red

Purpurea semi plena-double purple

Rubis-single red

Snowdrift-single, pure white

Totus Albus-single, pure white

Illinois, May 2.7, 1925 - Your stock was very fine, and came in number one shape. Thank you. 


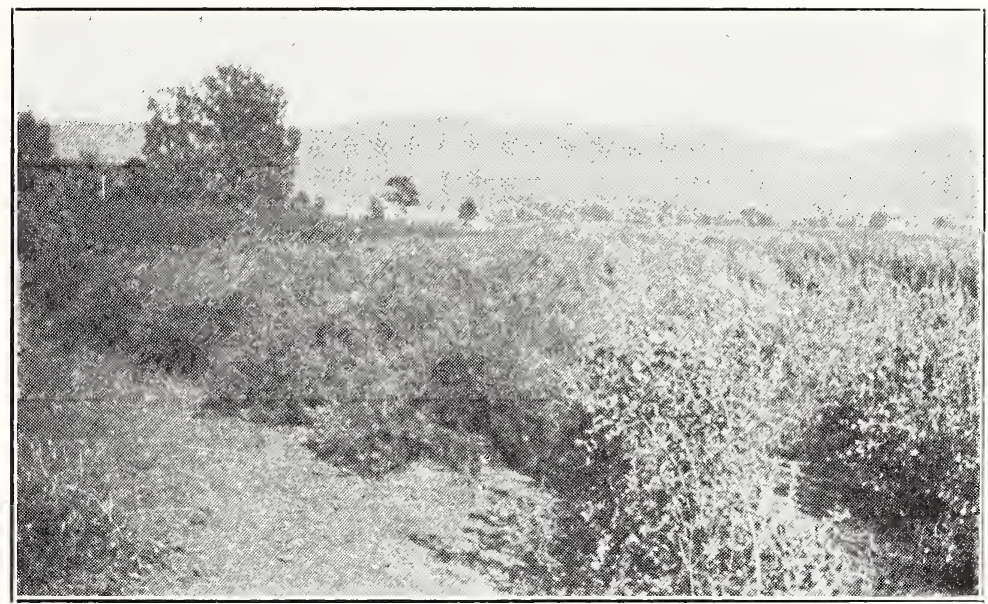

We will ship Spirea Prunifolia, Thunbergii, and White Snowberry from this Block

\section{DECIDUOUS SHRUBS-(Continued).}

AMYGDALUS nana alba (White Flowering Almond)

2 to 3 feet, well branched

Cipher

Per 100

18 to 24 inches, well branched

Sad

$\$ 15.00$

nana rosea (Pink Flowering Almond)

2 to 3 feet, well branched

Saddle

18 to 24 inches, well branched

Safe

45.00

35.00

BUDDLEIA davidii magnifica (Butter ay Bush)

2 years, No 1

Saffron

20.00

CALYCANTHUS florida (Sweet Shrub)

2 to 3 feet, well branched _._. Sail

40.00

18 to 24 inches, well branched

Saint

30.00

CARYOPTERIS incana (Mastacanthus) Blue Spirea

24 to 30 inches, well branched

Salad

25.00

18 to 24 inches, well branched

Salient

20.00

DEUTZIA crenata and Pride of Rochester

3 to 4 feet, well branched

Sallow

20.00

2 to 3 feet, well branched

Salmon

15.00

18 to 24 inches

Salon

10.00

EXOCHORDA grandiflora (Pearl Bush)

3 to 4 feet, well branched

Salt

45.00

2 to 3 feet, well branched

Salute

35.00

18 to 24 inches

Salvage

25.00

FORSYTHIA, Assorted

3 to 4 feet, well branched

Samp

2 to 3 feet, well branched

Sanction

Varieties: Fortunei Intermedia Viridissima Suspensa 


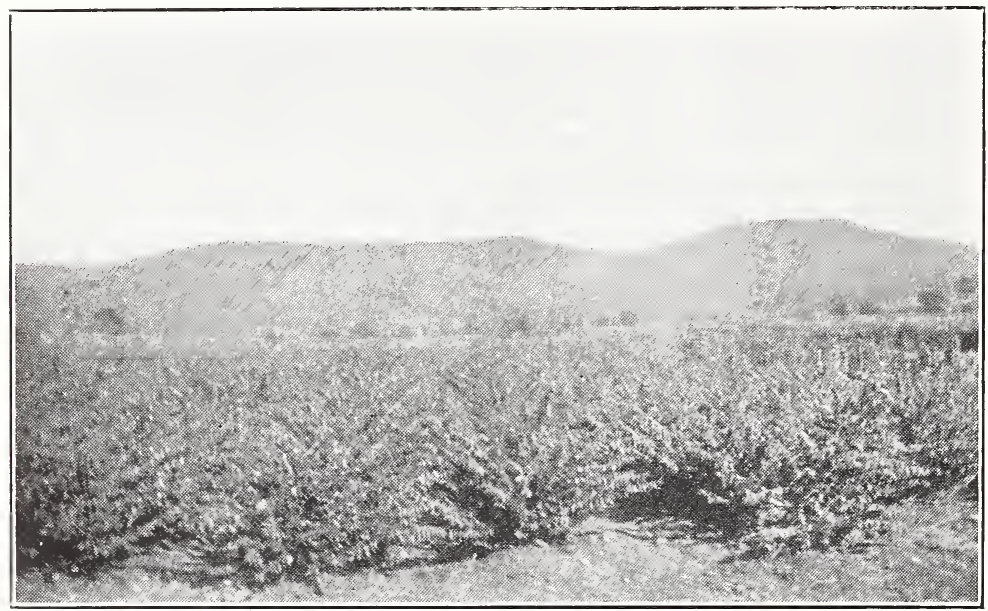

True Regelianum Privet, from Cuttings

DECIDUOUS SHRUBS-(Continued).

HAMAMELIS virginiana (Witch $\mathrm{Hazel}$ )

3 to 4 feet, well branched

Cipher

Sand

2 to 3 feet, well branched

Saneness

Per 100

$\$ 45.00$

35.00

HYDRANGEA arborescens grandiflora alba (Hills of Snow)

2 to 3 feet, well branched_.................. Sanitary

18 to 24 inches, well branched _............. Sappy

40.00

30.00

paniculata grandiflora

2 to 3 feet, well branched .................. Sarcasm

18 to 24 inches, well branched

Sardine

40.00

30.00

paniculata grandiflora, Tree Form

3 to 4 feet, well branched.

Sash

60.00

quercifolia (Oak Leaved Hydrangea)

2 to 3 feet, well branched

Satan

60.00

18 to 24 inches, well branched

Satchel

50.00

HYPERICUM moserianum (Gold Flower)

2 to 3 feet, heavy _..... Sateen

18 to 24 inches, well branched

Satin

35.00

12 to 18 inches, branched

Sauce

25.00

20.00

\section{gladioides}

18 to 24 inches, well branched

Sausage

30.00

12 to 18 inches, well branched

Savage

25.00

patulum henryi

2 to 3 feet, well branched

Saw

18 to 24 inches, well branched 


\section{DECIDUOUS SHRUBS-(Continued).}

JASMINUM nudiflorum (Yellow Jasmine) Cipher

3 years, extra heavy

Scab

Per 100

2 years, well branched

Scaffold

$\$ 30.00$

25.00

KERRIA japonica fora plena

3 to 4 feet, well branched

Scald

2 to 3 feet, well branched

Scamp

18 to 24 inches, branched

Scar

50.00

45.00

35.00

LAGERSTROEMIA indica (Crepe Myrtle)

3 to 4 feet, well branched

Scarce

40.00

2 to 3 feet, well branched

Scarlet

30.00

18 to 24 inches, well branched

Scatter

25.00

\section{Colors: Pink Purple Red}

LONICERA, Assorted

3 to 4 feet, well branched

Scene

20.00

2 to 3 feet, well branched

School

15.00

18 to 24 inches, well branched

Varieties: Fragrantissima Morrowi

Science

10.00

PHILADELPHUS, Assorted

3 to 4 feet, well branched

2 to 3 feet, well branched

18 to 24 inches

Pink Tartarian

Varieties:

Scion

20.00

15.00

Scoff

10.00

RHODOTYPOS kerrioides (White Kerria)

2 to 3 feet, well branched

Grandiflorus

Mont Blanc

Tradone

18 to 24 inches, well branched

Scorch

40.00

Scotch

30.00

SPIREA bumalda Anthony Waterer

24 to 30 inches, well branched

Scour

35.00

18 to 24 inches, well branched

Scow

22.00

15 to 18 inches, well branched

Scramble

18.00

12 to 15 inches, branched

Scrap

12.00

6 to 12 inches, branched

Scrawl

9.00

callosa rosea

3 to 4 feet, well branched

Scream

Scribe

18 to 24 inches, branched

Script

30.00

20.00

15.00

\section{prunifolia fora plena (Bridal Wreath}

4 to 5 feet, well branched.

Scroll

35.00

3 to 4 feet, well branched

Scrubby

25.00

2 to 3 feet, well branched

Scum

18 to 24 inches, well branched

Scuttle

20.00

15.00

\section{thunbergii}

24 to 30 inches, well branched _... Seal

30.00

18 to 24 inches, well branched

Seclude

25.00

12 to 18 inches, branched

Secrecy

17.50

van Houttei

3 to 4 feet, well branched

Sect

17.50

2 to 3 feet, well branched

Section

12.50

18 to 24 inches, well branched

Sedan

8.00 


\section{DECIDUOUS SHRUBS-(Continued)}

\section{SYMPHORICARPOS racemosus (Snowberry)}

2 to 3 feet, well branched.

18 to 24 inches, well branched

\section{SYRINGA vulgaris (Purple Lilac)}

2 to 3 feet, branched

18 to 24 inches, branched

TAMARIX hispida aestivalis

3 to 4 feet, well branched

2 to 3 feet, well branched

18 to 24 inches, branched.

\section{WEIGELA hendersonia}

3 to 4 feet, well branched

2 to 3 feet, well branched

18 to 24 inches, well branched
Cipher

Sedge

Sediment

Per 100

$\$ 20.00$

15.00

25.00

20.00

Segment

Seize

35.00

Selvage

Seminary

25.00

Semite

rosea

3 to 4 feet, well branched

Senate

25.00

Senior

17.50

12.50

2 to 3 feet, well branched

Sentence

25.00

18 to 24 inches, well branched

Sentry

17.50

Sepoy

Alabama, November 16, 1925.--Cherries were simply fine. Thanks.

North Carolina, October 30, 1925.-We have always found your stock first class and true to name.

North Carolina, November 8, 1925.-I must say you sent us the finest lot of trees we ever crdered.

Tennessee, November 7, 1925.--Thanking you for the nice plants sent and for the courtesy extended.

Illinois, November 10, 1925.- The shrubbery came Saturday. It is fine. I shall send for more stock soon.

Alabama, February 2, 1926.-J J tot received the shipment of shrubbery, and glad to say it is real nice stock.

Alabama, November 30, 1925.-We are glad to tell you that we get our best trees from you. Your stock is simply dandy.

Tennessee, November 30, 1925.-Check inclosed for $\$ 327.50$, in payment of account for fall. Stock was satisfactory in every way.

Tennessee, November 20, 1925.-I will get most of my stock from you, as everything I have ever gotten from you has been satisfactory.

Alabama, Norember 19, 1925.-Please find inclosed check on our account. The plums and cherries were the finest I have ever seen, I think.

Indiana, November 9, 1925.--Thanking you for your special attention to this order, and assuring you we appreciate your wonderful stock and your A-1 service, we remain, with best wishes.

Tennessee, December 21, 1925.--We want to say that all of the shipment was received in very fine condition. We wish to thank you for your attention to this order, and will send you check on January 1.

Indiana, February 4, 1926.-Thanking you in advance for your special attention to this order, and loping to receive some real choice stock, the same as you have heretofore furnished us, we are, yours very truly. 
ANNUAL WHOLESALE PRICE LIST

\author{
OF THE
}

FRASER NURSERY

COMPANY

(INCORPORATED)

HUNTSVILLE, ALABAMA

IT PAYS Pilc TO PLANT

\title{
IMPORTANT!
}

This list is intended to reach only those entitled to Wholesale Trade Prices. Errors are sometimes made, and in order that our mailing list may be corrected, we will thank any one in the trade to advise us should they have knowledge of our list reaching parties not so entitled.

For Nurserymen, Florists, Seedmen and Dealers Only 


\section{CUSTOMS OF THE TRADE}

PRICES quoted herein are not good after April 1, 1927, and are subject to cancellation without notice any time unless previously agreed upon.

CASH or satisfactory reference, with sufficient time to investigate before shipment, is invariably required of parties unknown to us. To responsible, prompt paying parties, we will extend usual time for payment.

REMITTANCES should be made by Draft on New York, Chicago, or St. Louis, or by Express or Postal Money Order.

CLAIMS for damages or deficiencies to receive consideration must be made promptly upon receipt of goods.

RATES apply as foilows: When 10 trees and not over 50 are ordered, the price will be $2 \frac{1}{2}$ cents per tree more than the price per 100 . Orders for 50 trees or more up to 300 , when not less than 10 trees of each variety, will be charged at the price per 100. Orders for 300 trees or more, when not less than 10 trees of each variety, will be charged for at the price per 1000 .

TELEGRAMS - Use Nurseryman's Telegraphic Code, copy of which we will mail upon request. In connection with this we give a cipher word for each grade. When this cipher word is used either in mail or telegraphic orders no other description of the stock is necessary.

PACKING-We believe we excel others in the manner of handling stock. This is due largely to personal experience and supervision. We pack to insure contents from drying or freezing, even though the shipment be delayed in transit.

\section{The cost of new boxes, well made, to be added, as follows:}

$30 \times 30 \times 7 \frac{1}{2}$ to 10 feet $\ldots \ldots \ldots . . \$ 4.00$

$24 \times 30 \times 7 \frac{1}{2}$ to 10 feet $\ldots \ldots . . . . .30$

$24 \times 2+x 7 \frac{1}{2}$ to 10 feet $\ldots \ldots . . . . . . .3 .00$
$18 \times 24 \times 7 \frac{1}{3}$ to 10 feet
$18 \times 18 \times 7 \times \frac{1}{2}$ to 10 feet
$15 \times 15 \times 7 \frac{1}{2}$ to 10 feet

Bales 50 cents and up, according to size.

SHIPMENTS-When ordering, please state plainly whether freight or express shipment is desired, and give route if by freight. In the absence of this information we will use our best judgement without assuming any responsibility as to delivery. Goods are at purchaser's risk and cost after delivery to the forwarding company. Under the Parcel Post system we are often able to forward small packages for less than the rates charged by express companies. Parties desiring to secure the benefits of Parcel Post should include sufficient for postage in their remittances; the difference, if any, will be refunded promptly.

NON-WARRANTY-We give no warranty, express or implied, as to description, quality, productiveness, or any other matter, of any nursery stock, seeds, bulbs or plants we sell.

CAUTION-All orders are accepted upon the condition that they shall be void should any injury befall the stock from frost, hail, fire or other causes beyond our control.

REFERENCES-Any Bank or Business House in Huntsville, Alabama, or either of the Mercantile Agencies. 


\section{ROSES-Field Grown, Budded and On Own Roots}

(H. P.) Hybrid Perpetıal, (H. W.) Hybrid Wichuriana, (H. C.) Hardy Climbing, (Mtf.) Multiflora, (S.) Setigera, (C. P.) Climbing Polyantha, (C. T.) Climbing Tca and Ramblers, No. 1, graded 3 or more branches 24 to 30 inches in length; No. 2, graded 2 and 3 branches 18 to 24 inches in length.

(T.) Tca and (H.T.) Hybrid Tea, No. 1, graded 3 or more branches 18 to 24 inches in length; No. 2, graded 2 and 3 branches 12 to 18 inches in length.

(B.) Budded. (O. R.) Own Roots.

American Pillar- $\mathrm{CP}$ - large bunches of pink (O. R.) - -

Bessie Brown-H'T-creamy white $(\mathrm{B}) \ldots$

Climbing American Beauty-HC-rich red (O. R.) -

Conrad F. Meyer-HR-bright pink (B)

No 1

No 2

Per 100

$\$ 20.00$

Per 100

35.00

$\$ 10.00$

25.00

$30.00 \quad 20.00$

Crimson Rambler-rich crimson (O. R.)

$20.00 \quad 10.00$

Dorothy Perkins--HW-bright pink (O. R.)

$20.00 \quad 10.00$

Empress of China-HC-bright red (O. R.)

20.00

10.00

Etoile de Lyon-T-bright sulphur yellow (B)

$35.00 \quad 25.00$

Excelsa-HW-Red Dorothy Perkins (O. R.)

$20.00 \quad 10.00$

Frau Karl Druschki-HP-pure white (B)

$30.00 \quad 20.00$

General Jacqueminot- $\mathrm{HP}$ - bright red (B)

$30.00 \quad 20.00$

Gruss an Teplitz-HT-fiery crimson (B)

$35.00 \quad 25.00$

Heinrich Munch-HP-a true pink Druschki (B)

Heart of Gold-HW-New. Velvety Crimson (O. R.)

Hiawatha-HW- single crimson (O. R.)

$30.00 \quad 20.00$

$50.00 \quad 40.00$

$20.00 \quad 10.00$

$35.00 \quad 25.00$

Jonkherr J. L. Mock-H'T-clear pink (B)

K. A. Victoria-H'T-pure white (B)

Madam Plantier-HP-pure white (O. R.) -

35.00

25.00

Maman Cochet-T-rosy pink (B)

$20.00 \quad 10.00$

$35.00 \quad 25.00$

Mary Wallace-HW-New. Rosy pink (O. R.)

Ophelia-HT-brilliant Salmon-flesh (B)

Paul Neyron-HP-deep rose (B)

Pauls Scarlet Climber-HW-vivid scarlet (B)

Pink Roamer-HW-single pink (O. R.)

President Taft-HT-deep pink (B)

$40.00 \quad 30.00$

$35.00 \quad 25.00$

$30.00 \quad 20.00$

$30.00 \quad 20.00$

$20.00 \quad 10.00$

$35.00 \quad 25.00$

$25.00 \quad 15.00$

Radiance-H'T-brilliant rosy carmine (B)

Red Radiance-H'T-bright pure red (B)

$35.00 \quad 25.00$

$\begin{array}{ll}35.00 & 25.00\end{array}$

Red Letter Day-H'T-glowing scarlet crimson (B) ...

Rhea Reid-H'T-rich, velvety red $(\mathrm{B})_{-}$

$35.00 \quad 25.00$

$35.00 \quad 25.00$

$20.00 \quad 10.00$

Tausendschoen-Rambler-deep pink (O. R.) $\quad 25.00 \quad 15.00$

Ulrich Brunner-HP-Hardy American Beauty (B) _. $\quad 30.00 \quad 20.00$

White Dorothy Perkins - HW-(O. R.) 


\section{HARDY PERENNIALS}

Cannas, King Humbert, Yellow King

Humbert and Eureka (White), strong roots...... $\$ 6.00$

Pachysandra terminalis (Japanese Spurge)

2 year, nice clumps.

Phlox, assorted varieties

12.00

Tuberose, Excelsior Pearl $\ldots 0$

Tuberose, Mexican

4.00

\section{LINING OUT STOCK}

Euonymus carrierei, 2 years transplanted.

Ligustrum amurense (Amour River Hardy Privet)

transplanting grade

25.00

ovalifolium (California Privet)

good transplanting grade, suitable also for grafting

Lonicera fragrantissima (Upright Fragrant Honeysuckle

1 year, 12 to 18 inches._. 50.00

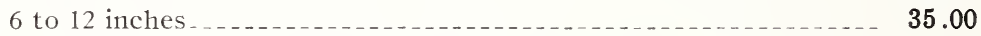

Melia azedarach umbraculifor mis ('Texas Umbrella

18 to 24 inches.

12 to 18 inches . 20.00

Spirea Anthony Waterer, 2 year transplanted _____ $\quad \mathbf{4 5 . 0 0}$

prunifoıia, 2 year transplanted._. 50.00

thunbergi, 2 year transplanted_._._._. $\quad 50.00$

van Houttei, 1 year, transplanting grade............... 20.00

Weigela hendersonia, 1 year transplanting grade $\ldots \ldots \ldots \ldots \ldots \ldots . .04$

rosea, 1 year transplanting grade._._._._._._. $\quad 45.00$

Indiana, February 2, 1926.-It is, no doubt, useless for us to mention about your keeping up your wonderful reputation with us by shipping excellent stock, as we feel that you will ship us the best you have.

Ohin, March 11, 1926.--Inclosed find check for $\$ 89.75$. Goods arrived in good shape. I wish you would ship the following order:

North Caroina, February 20, 1926.-Received the Texas Umbrella (). K. They were fine. Will send you an order later.

Alabama, February 17, 1926.-I was very much pleased with the nice lot of shrubbery you shipped me.

Mississippi, March 25, 1926.-All plants were received in excellent condition. 



\section{IT PAYS FIC TOPLANT}

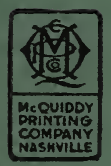

